\title{
The Lesser Wax Moth Achroia grisella (Lepidoptera: Pyralidae): A New Diet for Rearing Three Predatory Mites of the Family Phytoseiidae
}

\author{
M. F. HASSAN ${ }^{1}$, F. M. MOMEN ${ }^{2 *}$, S. S. MOAWAD² and M. LAMLOM² \\ ${ }^{1}$ Department of Zoology and Agriculture Nematology, Faculty of Agriculture, Cairo University, Egypt \\ ${ }^{2}$ Pests and Plant Protection Department, National Research Centre (NRC), \\ 31 El-Bouhoth Street, 12311 Dokki, Cairo, Egypt
}

(Received: 3 March 2019; accepted: 14 June 2019)

\begin{abstract}
The predatory mites Neoseiulus barkeri, Amblyseius swirskii and Cydnoseius negevi are native phytoseiid mites in Egypt. The biology of these predators was studied using Achroia grisella eggs as food source. Tested phytoseiids were succeeded to develop to adulthood and sustain oviposition on A. grisella eggs. For Cydnoseius negevi, the development was slower and fecundity was lower than for Neoseiulus barkeri and Amblyseius swirskii. The predation rate during immature stages of Cydnoseius negevi was higher than those of Neoseiulus barkeri and Amblyseius swirskii. During oviposition period, N. barkeri consumed more eggs than other phytoseiids did. The higher mean fecundity was recorded for Neoseiulus barkeri and Amblyseius swirskii as opposed to the lower mean for Cydnoseius negevi. When Amblyseius swirskii fed on Achroia grisella eggs, the oviposition period, female longevity and mean generation time were longer than for Cydnoseius negevi and Neoseiulus barkeri. Feeding on eggs of Achroia grisella resulted in the lowest mean fecundity, net reproductive rate, intrinsic rate of natural increase, finite rate of increase and gross reproductive rate for Cydnoseius negevi. The sex ratio of all predators' progeny was in female-biased. Consequently, the moth egg was alternative food for Neoseiulus barkeri and Amblyseius swirskii, while it considers as survival prey for Cydnoseius negevi.
\end{abstract}

Keywords: Generalist predators, Phytoseiidae, Achroia grisella, biological control, alternative food.

One of the most valuable products of honey bees is the wax. It is used in the pharmacological industry, dentistry and cosmetics. Pollen and honey are very important nutrients mining from wax and is therefore attacked by various pests (Ebadi, 1975). The most economical and serious pests of wax are Galleria mellonella Linnaeus and Achroia grisella Fabricius (both Lepidoptera: Pyralidae) (Chang and Hsieh, 1992). Honeybee pests are known to cause significant losses, and to transmit viral pathogens for which therapies remain absent and continue to be difficult to eliminate (McMenamin and Genersch, 2015). In an effort to allow the production of predators at low cost, factitious items have been evaluated, i.e. alternative food sources that they would not normally found in their natural habitat. In addition, such different items of food can be useful as food supplements to support predator populations after release in the crop (Wade et al., 2008). Providing easily produced frozen, live, lyophilized insects and mites as primary food sources (fac-

\footnotetext{
* Corresponding author; e-mail: fatmomen@yahoo.com
} 
titious food) instead of natural prey that support the development and reproduction of predators may make the cost-effective rearing system economic (Zhang, 2003). Also, alternative/adequate foods which are easily offered and cheaper than the natural prey may give an increase to ease the rearing costs of natural enemies (Riahi et al., 2017a).

For example astigmatid mites and eggs of many lepidopterans have been considered useful for mass rearing predatory mites (Huang et al., 2013). This usually renders the rearing process less expensive than those using phytophagous mites as food, due to reduced requirements for space, labor and maintenance costs (Gerson et al., 2003).

The predatory mites Neoseiulus barkeri (Hughes), Amblyseius swirskii Athias-Henriot and Cydnoseius negevi (Swirski and Amitai) (all Acari: Phytoseiidae) are classified as members of type III generalist predators (McMurtry et al., 2013), able to develop on a wide range of natural foods like: Tetranychus urticae Koch (Acari: Tetranychidae), Thrips tabaci Lindeman (Thysanoptera: Thripidae), Bemisia tabaci (Gennadius) (Hemiptera: Aleyrodidae), Aculops lycopersici (Massee) (Acari: Eriophyidae) and pollen grains (Hansen, 1988; Abou-Awad et al., 1989; Momen, 1995; Momen and Abdel-Khalek, 2008; Arthurs et al., 2009) and factitious prey included Ephestia kuehniella Zeller (Lepidoptera: Pyralidae), Phthorimaea operculella (Zeller) (Lepidoptera: Gelechiidae), Aleuroglyphus ovatus Toupeau (Acari: Acaridae), decapsulated dry cysts of the brine shrimp Artemia franciscana Kellogg (Anostraca: Artemiidae), Carpoglyphus lactis (L.) (Acari: Carpoglyphidae) (El-Sawi and Momen, 2005; Momen and El-Laithy, 2007; Xia et al., 2012; Nguyen et al., 2014; Ji et al., 2015).

One of the main reasons for the choice of Neoseiulus barkeri, Amblyseius swirskii and Cydnoseius negevi is that able to target more one important prey at the same time ex: Neoseiulus barkeri (against thrips and spider mites), Amblyseius swirskii (against whiteflies, thrips, mites), Cydnoseius negevi (against whitefly and thrips) (van Lenteren, 2012; Negm et al., 2014). The second reason is that tested phytoseiids here are generalist commercialized predation capacity that are presently being used on worldwide scale as an augmentative biological control in many of vegetable greenhouses and fruit orchards (McMurtry et al., 2013; Buitenhuis et al., 2015).

The objective of this report was to test the acceptability of a new diet, Achroia grisella eggs for rearing Neoseiulus barkeri, Amblyseius swirskii and Cydnoseius negevi. Our studies includes the developmental periods, predation rates, all physiological parameters, reproductive performance and fertility life table of tested phytoseiid mites fed on eggs of Achroia grisella.

To our knowledge present study is the first showing the potential of Neoseiulus barkeri, Amblyseius swirskii and Cydnoseius negevi to feed and reproduce on Achroia grisella eggs.

\section{Materials and Methods}

\section{Phytoseiid mites}

The native phytoseiid mite, Cydnoseius negevi was collected from a mango orchard in Tanta Province, on March 11, 2016. Amblyseius swirskii and Neoseiulus barkeri were collected from eggplant fields in Faywam Province, on May 25, 2017. Cydnoseius negevi 
was reared on pollen grains of castor bean Ricinus communis L. (Euphorbiaceae), while Neoseiulus barkeri and Amblyseius swirskii were reared on Tetranychus urticae supplied as prey. All cultures of predatory mites were maintained separately on excised raspberry leaves spread on water-soaked cotton in Petri dishes at $30{ }^{\circ} \mathrm{C} \pm 1,70 \pm 5 \% \mathrm{RH}$ and a 18:6 h (L:D) photoperiod at NRC, Egypt. Drops of water were added to cotton wool when necessary to prevent mites from escaping and to maintain leaf freshness. Raspberry leaves were replaced by fresh ones every 2 weeks.

\section{Rearing of Achroia grisella}

The lesser wax moth, Achroia grisella was reared on an artificial diet according to Sawaf (1962) with some modification. The survival rate of Achroia grisella on the new artificial diet used presently was $95 \%$, respectively.

Females and males of the moth were collected from infested honey hives, and then released in plastic cups $(150 \mathrm{ml})$ for mating. A sheet from toilet tissue was hanged in the plastic cups for females to lay their eggs. Female moths oviposited between layers of tissues and to isolate it, one drop of water was added on eggs patch to facilitate tissue layer to be opened without any damage to the sticky eggs. The collected eggs were placed on an artificial diet and incubated at $27 \pm 1{ }^{\circ} \mathrm{C}$ and $70 \pm 5 \% \mathrm{RH}$. The hatched larvae were released to feed on artificial diet till pupation. Table 1 shows the main component of an artificial diet used for rearing Achroia grisella in the laboratory.

Table 1

Main component of an artificial diet used for rearing Achroia grisella at $27 \pm 1{ }^{\circ} \mathrm{C}$ and $\mathrm{RH}$ of $70 \pm 5 \%$

\begin{tabular}{ll}
\hline Quantity & Components \\
\hline $440 \mathrm{gm}$ & Wheat flour \\
$40 \mathrm{gm}$ & Corn flour \\
$240 \mathrm{gm}$ & Wheat bran \\
$120 \mathrm{gm}$ & Milk Powder \\
$10 \mathrm{gm}$ & Yeast \\
$100 \mathrm{ml}$ & Honey \\
$200 \mathrm{ml}$ & Glycerin \\
\hline
\end{tabular}

\section{Life histories and predation of tested phytoseiid mite species}

A single egg of each species of predatory mite was introduced into each rearing leaf disc. Arenas $(3 \times 3 \mathrm{~cm})$ of excised raspberry leaves, placed on water saturated cotton in plastic Petri dishes, were used to confine the predators. The development of predators was observed twice daily, and the stage of development was recorded at each observation. Since all predatory larvae develop to protonymphs without feeding, prey eggs were provided after the molt to the protonymphal stage. Insect eggs were transferred carefully to the leaf disks with a fine paintbrush. To determine the prey consumption by different stages of tested predatory mites, 8-10 Achroia grisella eggs were added daily to each leaf disc for all predators. After every $24 \mathrm{~h}$, the number of prey consumed was replaced daily by other fresh eggs to maintain an ample food supply. 
A newly emerged female of each predatory species from the development experiment was mated with an unmated male for one day in the rearing discs. The male was removed at the following day. Five days later, a new male of each species was introduced to each arena for repeated mating if necessary. All physiological periods and oviposition of the predatory females were observed daily until death. After being counted daily, the eggs of each female were transferred to a separated arena where they were reared on Achroia grisella eggs to adulthood for sex determination. Prey eggs consumed (completely or partially deflated, respectively), were recorded daily in each experiment until the predatory females died. Every $3 / 4$ days the predators were transferred to new discs. All experiments were maintained in rearing chambers under at $30 \pm 1{ }^{\circ} \mathrm{C}$ and $70 \pm 5 \% \mathrm{RH}$.

\section{Age-stage, two-sex life table}

Developmental time of all individuals, including male and female and female daily fecundity were analyzed according to the age-stage, two-sex life table theory (Chi and Liu, 1985) and the method described by Chi (1988).

The age-stage specific survival rate $\left(\mathrm{s}_{\mathrm{xj}}\right)$ (where $\mathrm{x}=$ age in days and $\mathrm{j}=$ stage); the age-stage specific fecundity $\left(\mathrm{f}_{\mathrm{xj}}\right.$ ) (daily number of eggs produced per female on age $\mathrm{x}$ ); the age-specific survival rate $\left(1_{x}\right)$; the age-specific fecundity $\left(\mathrm{m}_{\mathrm{x}}\right)$ (daily number of eggs produced per individual, i.e. this number is divided by all individuals (males and females) of age $\mathrm{x}$ ) and the population growth parameters (the intrinsic rate of increase $\left(\mathrm{r}_{\mathrm{m}}\right)$; the finite rate of increase $(\lambda)$ that $\lambda=\mathrm{e}^{\mathrm{r}}$; the gross reproductive rate (GRR); the net reproductive rate (R0) and the mean generation time (T)) are calculated.

The age age-specific survival rate includes both male and female, and is calculated according to Chi and Liu (1985) as:

$$
l_{x}=\sum_{j=1}^{k} s_{x j}
$$

and

$$
m_{x}=\frac{\sum_{j=1}^{k} S_{x j} f_{x j}}{\sum_{j=1}^{k} S_{x j}}
$$

Where $\mathrm{k}$ is the number of stages.

The intrinsic rate of increase is estimated by using iterative bisection method from:

$$
\sum_{x=0}^{w} e^{-r(x+1)} l_{x} m_{x}=1
$$

With age indexed from 0 to $\omega$ (maximum age).

The mean generation time is calculated as $\mathrm{T}=\ln \mathrm{R} 0 / \mathrm{r}$. The Ro is estimated by using:

$$
R_{0}=\sum_{x=0}^{w} \sum_{j=1}^{k} S_{x j} f_{x j}
$$


The GRR is calculated as GRR $=\Sigma \mathrm{m}_{\mathrm{x}}$.

Data analysis and population parameters $\left(\mathrm{r}_{\mathrm{m}}, \lambda, \mathrm{GRR}, \mathrm{R} 0\right.$ and $\left.\mathrm{T}\right)$ were calculated by using the TWOSEX-MSChart programme (Chi, 2017). The means and standard errors of the population parameters were estimated by using the Bootstrap procedure with 100,000 re-sampling and the life table parameters of tested predatory phytoseiid mites on eggs of Achroia grisella were compared by using a paired bootstrap test (Huang and Chi, 2013).

\section{Female age-specific life table}

In the female life table, the number of female progeny, survival rate of immature and female adult stages, daily fecundity and sex ratio were used for the estimation of different life table parameters. The estimated parameters were the age-specific survival rate (lx), age-specific fecundity (mx), $\mathrm{r}_{\mathrm{m}}, \lambda, \mathrm{GRR}, \mathrm{R} 0, \mathrm{~T}$.

The life table constructions were adopted from Birch (1948).

\section{Statistical analysis}

The mean duration of each immature and all physiological stages, longevity, predation rate and fecundity of Neoseiulus barkeri, Amblyseius swirskii and Cydnoseius negevi on Achroia grisella eggs were submitted to analyses of variance using one-way ANOVA and means compared by Tukey $(P=0.01$ level) using SPSS computer program. Data were fitted with the assumption of normality, not transformed, and differences were compared for all tested predators on Achroia grisella eggs.

\section{Results}

Influence of Achroia grisella eggs on life histories and predation of Neoseiulus barkeri, Amblyseius swirskii and Cydnoseius negevi

The developmental times of immature stages and adult longevities periods of Amblyseius swirskii, Neoseiulus barkeri and Cydnoseius negevi fed on Achroia grisella eggs are demonstrated in Table 2. Pre-adult individuals of predatory species could develop to adult with Achroia grisella eggs. The durations of egg and larval stages of all tested predators were similar.

The duration of protonymphal stage of Cydnoseius negevi was significantly longer than that of Neoseiulus barkeri and Amblyseius swirskii. The significantly shortest developmental duration was observed in Neoseiulus barkeri (Table 2). Insignificant differences were observed in the duration of deutonymphal stage for Amblyseius swirskii and Cydnoseius negevi and also between Neoseiulus barkeri and $C$. negevi. The results showed that all tested predators larvae did not feed on insect eggs. The consumption rates of Cydnoseius negevi, Amblyseius swirskii and Neoseiulus barkeri females are summarized in Table 3. Protonymphs and deutonymphs of Cydnoseius negevi were consumed significantly more amount of Achroia grisella eggs than those of Neoseiulus barkeri and Amblyseius swirskii did. Females of Amblyseius swirskii had significantly longer 
Table 2

Developmental periods (mean $\pm \mathrm{SE}$ in days) of Neoseiulus barkeri, Amblyseius swirskii and Cydnoseius negevi females fed on Achroia grisella eggs at $30 \pm 1{ }^{\circ} \mathrm{C}$ and $70 \pm 5 \%$ R.H.

\begin{tabular}{lcccr}
\hline Developmental stages & \multicolumn{3}{c}{ Predatory phytoseiid mites } & Calculated \\
& $n$ & $\begin{array}{l}\text { Amblyseius swirskii } \\
\text { Neoseiulus barkeri } \\
(30)^{\mathrm{z}}\end{array}$ & $\begin{array}{l}\text { Cydnoseius negevi } \\
(30)\end{array}$ & - \\
\hline Egg & $3.00 \pm 0.00$ & $3.00 \pm 0.00$ & $3.00 \pm 0.00$ & - \\
Larva & $1.00 \pm 0.00$ & $1.00 \pm 0.00$ & $1.00 \pm 0.00$ & 151.057 \\
Protonymph & $2.43 \pm 0.08 \mathrm{c}^{\mathrm{y}}$ & $3.33 \pm 0.09 \mathrm{~b}$ & $4.60 \pm 0.09 \mathrm{a}$ & 8.298 \\
Deutonymph & $1.74 \pm 0.07 \mathrm{~b}$ & $2.17 \pm 0.07 \mathrm{a}$ & $1.93 \pm 0.05 \mathrm{ab}$ & 163.919 \\
Lifecycle & $8.20 \pm 0.07 \mathrm{c}$ & $9.50 \pm 0.10 \mathrm{~b}$ & $10.53 \pm 0.09 \mathrm{a}$ & 51.655 \\
Pre-oviposition & $1.00 \pm 0.00 \mathrm{~b}$ & $2.63 \pm 0.19 \mathrm{a}$ & $1.33 \pm 0.09 \mathrm{~b}$ & 508.162 \\
Oviposition & $9.57 \pm 0.12 \mathrm{~b}$ & $10.73 \pm 0.27 \mathrm{a}$ & $2.83 \pm 0.14 \mathrm{c}$ & 124.887 \\
Post-oviposition & $1.40 \pm 0.09 \mathrm{~b}$ & $0.37 \pm 010 \mathrm{c}$ & $3.20 \pm 0.17 \mathrm{a}$ & 207.620 \\
Adult longevity & $11.97 \pm 0.16 \mathrm{~b}$ & $13.73 \pm 0.35 \mathrm{a}$ & $7.37 \pm 0.10 \mathrm{c}$ & 118.170 \\
Life span & $20.17 \pm 0.18 \mathrm{~b}$ & $23.23 \pm 0.35 \mathrm{a}$ & $17.90 \pm 0.15 \mathrm{c}$ & \\
\hline
\end{tabular}

${ }^{y}$ Within a row, means followed by a common letter do not differ significantly (Tukey HSD, a = 0.01, df = 2,87).

${ }^{\mathrm{z}}$ Number in brackets refers to number of replicates.

pre-oviposition and oviposition periods than that of Cydnoseius negevi and Neoseiulus barkeri $\left(F_{2,87}=51.655,508.162, P=0.0001\right)$. Individuals of Cydnoseius negevi fed on Achroia grisella eggs had the shortest oviposition $\left(F_{2,87}=508.162, P=0.0001\right)$ and longest post-oviposition periods $\left(F_{2.87}=124.887, P=0.0001\right)$ among Neoseiulus barkeri and Amblyseius swirskii. Mean oviposition period, adult longevity and life span were statistically shorter in Cydnoseius negevi than for Amblyseius swirskii and Neoseiulus barkeri (oviposition period: $F_{2,87}=508.162$; adult longevity: $F_{2,87}=207.602$; life span: $\left.F_{2,87}=118.175, P=0.0001\right)$. The total predation rate increased from pre-oviposition to oviposition periods and reduced in the post-oviposition phase of Neoseiulus barkeri and Amblyseius swirskii. During female longevity, Neoseiulus barkeri and Amblyseius swirskii were consumed similar amount of Achroia grisella eggs and higher than those of Cydnoseius negevi. Among the predators, the total and daily consumption rate was significantly higher during the oviposition periods of Neoseiulus barkeri (47.07eggs/ $\%$, $4.93 \mathrm{eggs} /$ / day) followed by Amblyseius swirskii (42.43 eggs/Q, 3.97 eggs/ $\$ /$ day) and Cydnoseius negevi (7.97 eggs/ $Q$, 2.81/Q/ day) $\left(F_{2,87}=827.058, P=0.0001\right)$ (Table 2$)$.

\section{Age-stage, two-sex life table}

The age-stage specific survival rates $\left(s_{x j}\right)$ of tested phytoseiid mites (Fig. 1) show the probability that a newborn will survive to age $x$ and develop to stage $j$. These curves also show the survivorship and stage differentiation as well as the variable developmental rate. The probability that a newborn egg survived to the adult stage was $0.86,0.86$ and 0.86 for females and 0.14, 0.14 and 0.14 for males of Amblyseius swirskii, Neoseiulus barkeri and Cydnoseius negevi, respectively. 
Age-specific survivorship, age and age-stage-specific fecundity

The age-specific survivorship ( $l x)$ and age-specific fecundity $(m x)$ of predatory phytoseiid mites reared on Achroia grisella eggs are shown in Fig. 2. These curves indicate that all tested phytoseiid species completed its development and reproduced on Achroia grisella eggs. The mean number of offspring produced by phytoseiid individuals of the age $\mathrm{x}$ and stage $\mathrm{j}$ per day is shown with the age-stage-specific fecundity $\left(f_{\mathrm{xj}}\right)$ in Fig. 2. The start of oviposition of the first female of Amblyseius swirskii, Cydnoseius negevi and
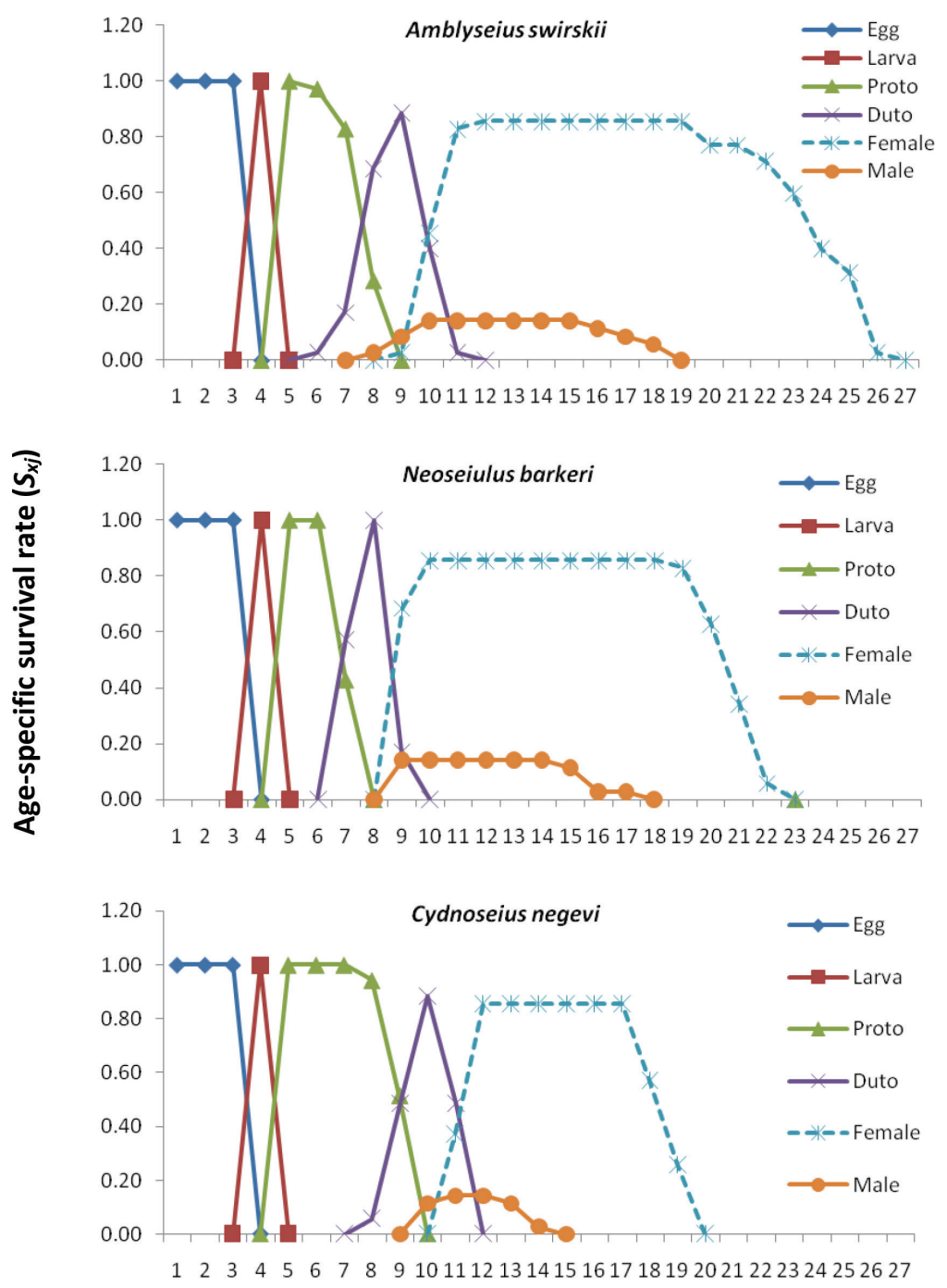

\section{Age (days)}

Fig. 1. Age-stage survival rate $\left(\mathrm{S}_{\mathrm{xj}}\right)$ of Amblyseius swirskii, Neoseiulus barkeri and Cydnoseius negevi on Achroia grisella eggs 


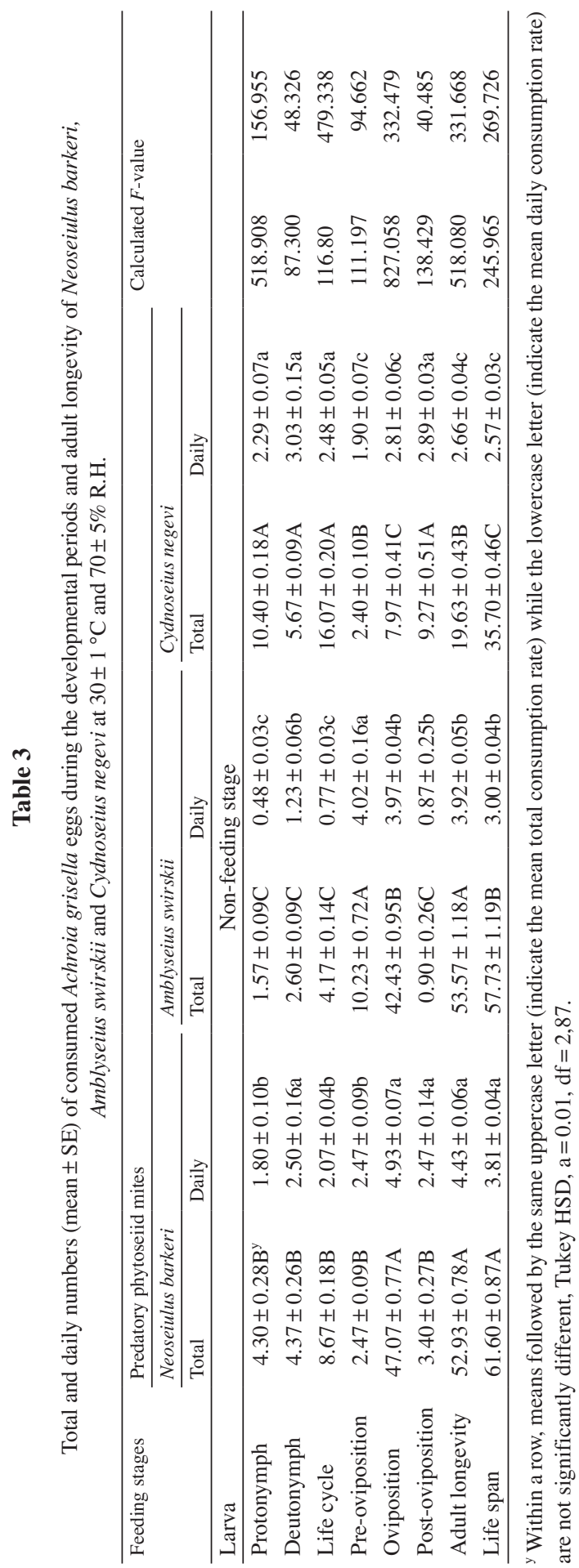


Neoseiulus barkeri occurred at the age 8, 10 and 8 days, respectively. The highest daily fecundity (peak of $f i$, female) of above phytoseiids on insect eggs was 2.0, 1.20 and 2.30 eggs, respectively, that occurred at the age of 13.0, 11.8 and 14.0 days, respectively.

\section{Two-sex life table parameters}

The fecundity and life table parameters of Amblyseius swirskii, Neoseiulus barkeri and Cydnoseius negevi fed on Achroia grisella eggs is shown in Table 4.

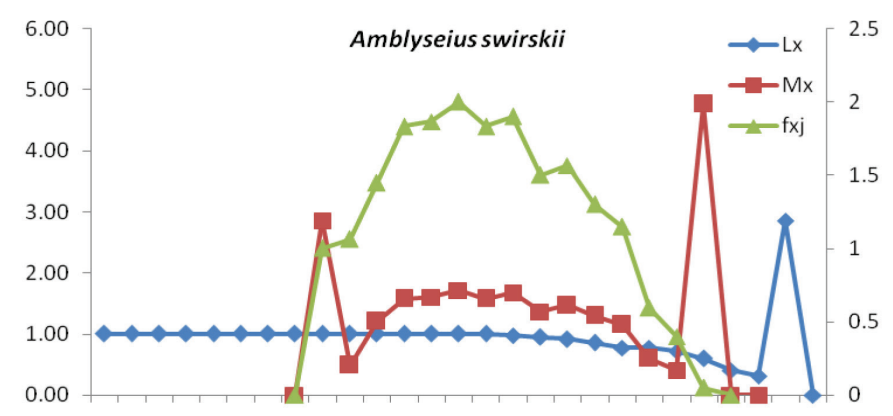

1234456789101112131415161718192021222324252627
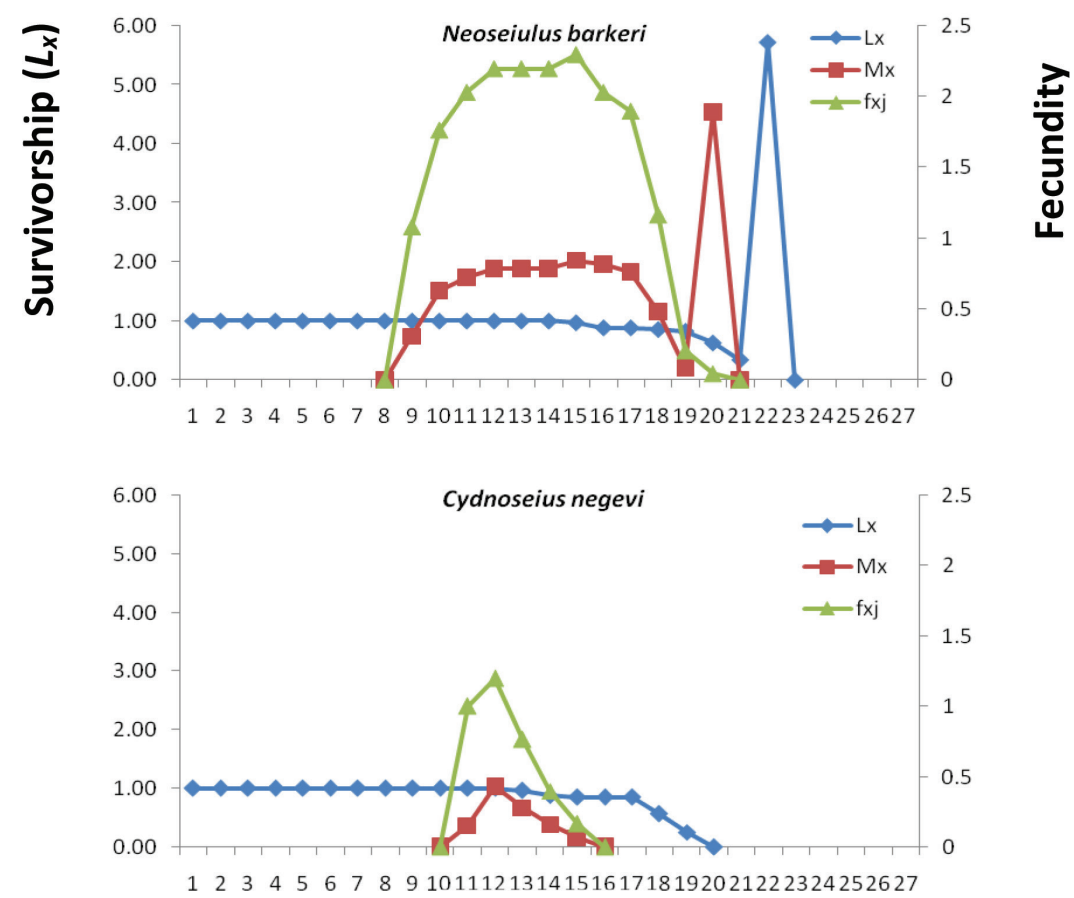

Age (days)

Fig. 2. Age-specific survival rate (lx), age-stage fecundity of female $\left(f_{x j}\right)$ and age-specific fecundity rate (mx) of Amblyseius swirskii, Neoseiulus barkeri and Cydnoseius negevi on Achroia grisella eggs 
Table 4

Fecundity and life table parameters (mean \pm SE) of Neoseiulus barkeri, Amblyseius swirskii and Cydnoseius negevi fed on Achroia grisella eggs at $30 \pm 1{ }^{\circ} \mathrm{C}$ and $70 \pm 5 \%$ R.H.

\begin{tabular}{|c|c|c|c|c|}
\hline \multirow[t]{2}{*}{ Life table parameters } & \multicolumn{3}{|c|}{ Predatory phytoseiid mites } & \multirow[b]{2}{*}{$F$} \\
\hline & $\begin{array}{l}\text { Neoseiulus barkeri } \\
(30)^{\mathrm{z}}\end{array}$ & $\begin{array}{l}\text { Amblyseius swirskii } \\
(30)^{\mathrm{z}}\end{array}$ & $\begin{array}{l}\text { Cydnoseius negevi } \\
(30)^{\mathrm{z}}\end{array}$ & \\
\hline Mean total fecundity /Q & $18.83 \pm 0.23 \mathrm{a}^{\mathrm{y}}$ & $17.70 \pm 0.46 \mathrm{a}$ & $3.00 \pm 0.00 \mathrm{~b}$ & 891.202 \\
\hline Mean daily no. of eggs /Q & $1.98 \pm 0.029 a$ & $1.66 \pm 0.03 b$ & $1.13 \pm 0.055 \mathrm{c}$ & 109.845 \\
\hline Net reproductive rate $(\mathrm{R} 0)$ & $16.2 \pm 1.133 \mathrm{a}$ & $15.2 \pm 1.130 \mathrm{~b}$ & $2.543 \pm 0.177 \mathrm{c}$ & 2800.0 \\
\hline Intrinsic rate of increase $\left(\mathrm{r}_{\mathrm{m}}\right)$ & $0.2150 \pm 0.006 \mathrm{a}$ & $0.188 \pm 0.006 b$ & $0.075 \pm 0.006 \mathrm{c}$ & 5679.0 \\
\hline Finite rate of increase $(\lambda)$ & $1.239 \pm 0.007 \mathrm{a}$ & $1.206 \pm 0.007 b$ & $1.077 \pm 0.006 \mathrm{c}$ & 5488.1 \\
\hline Mean generation time $(\mathrm{T})$ & $12.958 \pm 0.085 b$ & $14.987 \pm 0.135 \mathrm{a}$ & $12.508 \pm 0.122 c$ & 2770.2 \\
\hline Gross reproductive rate (GRR) & $16.91 \pm 0.876 \mathrm{a}$ & $16.17 \pm 0.895 b$ & $2.63 \pm 0.147 \mathrm{c}$ & 5128.1 \\
\hline Sex ratio (female/total) $\%$ & 0.66 & 0.63 & 0.56 & \\
\hline ○: Ơ & $250 \bigcirc: 130 \sigma^{\prime \prime}$ & $223 \circ: 1290^{\circ}$ & @45 : O’35 & \\
\hline
\end{tabular}

${ }^{\mathrm{y}}$ Means within a row fallowed by common letter do not differ significantly, Tukey HSD, $\mathrm{a}=(0.01)$. $\mathrm{df}=2,87$.

${ }^{\mathrm{z}}$ Number between parentheses represents number of replicates.

Based on the age-stage, two-sex life table, for all the measured parameters: net reproductive rate $(\mathrm{R} 0)$, intrinsic rate of increase $\left(r_{\mathrm{m}}\right)$, mean generation time $(\mathrm{T})$, finite rate of increase $(\lambda)$, gross reproductive rate (GRR), the value of (R0) of Neoseiulus barkeri females fed insect eggs was significantly higher than that for Amblyseius swirskii and Cydnoseius negevi females. Amblyseius swirskii had a longer generation time than that for other predatory females. The (GRR) and ( $\lambda$ ) were higher in Neoseiulus barkeri than that of Amblyseius swirskii and Cydnoseius negevi.

\section{Age-stage reproductive value}

The age-stage reproductive value $\left(\mathrm{v}_{\mathrm{xj}}\right)$ is the contribution of individuals of age $\mathrm{x}$ and stage $\mathrm{j}$ to the future population. The reproductive value for a new egg $\left(\mathrm{v}_{01}\right)$ of $A m$ blyseius swirskii, Cydnoseius negevi and Neoseiulus barkeri on Achroia grisella eggs is the finite rate of increase $(\lambda)$ (Fig. 3). The peak reproductive (Fig. 3) was at the age of 11, 10 and 9 days for Amblyseius swirskii, Cydnoseius negevi and Neoseiulus barkeri fed on insect eggs, respectively. This implies that, in comparison with other ages, female individuals of the ages 11, 10 and 9 days made the highest contribution to the population when fed on Achroia grisella eggs, respectively. The total number of eggs deposited by Neoseiulus barkeri and A. swirskii females fed on Achroia grisella eggs was statistically similar and higher than that for Cydnoseius negevi females $\left(F_{2,87}=891.202, P=0.0001\right)$. The very low fecundity of Cydnoseius negevi led to very low intrinsic rates of increase and net reproductive rates on insect eggs.

\section{Discussion}

The present study revealed that Achroia grisella eggs was accepted by different life stages of Neoseiulus barkeri, Amblyseius swirskii and Cydnoseius negevi females and 
sustained the development and reproduction. Few studies have been carried out on the life history of tested phytoseiid predators being fed on various insects' egg. When Amblyseius swirskii and Neoseiulus barkeri were fed on natural prey such as: Thrips tabaci, Tetranychus urticae, Eutetranychus orientalis (Klein), Oligonychus afrasiaticus (McGregor), Aculus fockeui (Nalepa and Trouessart) (Acari: Eriophyidae), Aculops lycopersici and almond pollen, the developmental period of both species was considerably shorter than on Achroia grisella eggs in the present study (Momen, 1995; Momen and El-Borolossy, 1999; Abou-Elella, 2003; Momen and Abdel-Khalek, 2008; Momen, 2009; Negm et al., 2014; Riahi et al., 2017a). When Cydnoseius negevi fed on natural foods as R. communis, B. tabaci, Aculus fockeui (Momen, 2009; Momen et al., 2009), and the developmental

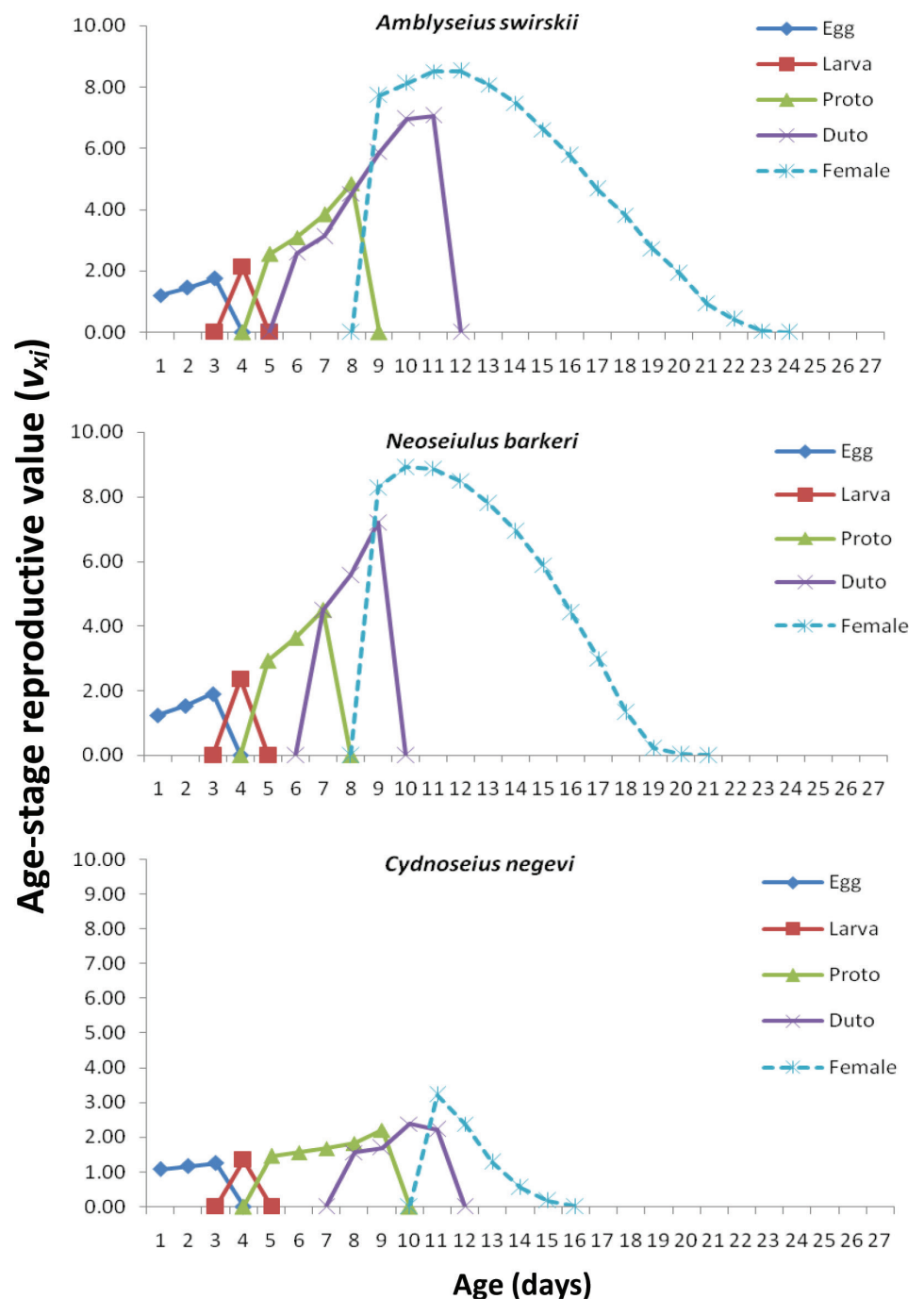

Fig. 3. Age-stage reproductive value $\left(\mathrm{V}_{\mathrm{xj}}\right)$ of Amblyseius swirskii, Neoseiulus barkeri and Cydnoseius negevi on Achroia grisella eggs 
period was shorter than on eggs of Achroia grisella tested here. Whereas Amblyseius swirskii and Neoseiulus barkeri preying on some unnatural foods ex: Ephestia kuehniella and Phthorimaea operculella eggs, Suidasia medonensis Oudemans (Acari: Suidasiidae), Carpoglyphus lactis and Bactrocera zonata eggs (Saunders) (Diptera: Tephritidae), the developmental period of both species was shorter than on eggs of Achroia grisella (ElSawi and Momen, 2005; Momen and El-Laithy, 2007; Midthassel et al., 2013; Nguyen et al., 2014; Ji et al., 2015; Momen et al., 2016). Cydnoseius negevi has not cited before to feed on unnatural foods. The immature stages of Cydnoseius negevi consumed more than twice/four times of Achroia grisella eggs than those of Neoseiulus barkeri and Amblyseius swirskii did, respectively. El-Sawi and Momen (2005) reported a higher consumption rate by Amblyseius swirskii females on Phthorimaea operculella (73.9 eggs) and Spodoptera littoralis eggs Boisduval (Lepidoptera: Noctuidae) (78.8 eggs) than those fed Achroia grisella eggs. Neoseiulus barkeri consumed more B. zonata eggs (70.44 eggs/o) during adult longevity opposed to (52.93/o) on Achroia grisella eggs (Momen et al., 2016). The females longevity of Amblyseius swirskii was longer on Phthorimaea operculella (23.5 days), S. littoralis (29.8 days), Ephestia kuehniella (44.12 days) than those fed Achroia grisella eggs (13.73 days) (El-Sawi and Momen, 2005; Nguyen et al., 2014), respectively. Also, Neoseiulus barkeri had longer an adult longevity more than (2.5 times) on Bactrocera zonata (29.17 days) and (3 times more) on Ephestia kuehniella (43.0 days) than on Achroia grisella eggs in the present study (Momen and El-Laithy, 2007; Momen et al., 2016). These variations in developmental and physiological periods and predation rates could be attributed to different prey studied and the environmental factors. The oviposition rate and all demographic parameters of Cydnoseius negevi was extremely lower than that on other tested natural foods (Momen, 2009; Momen et al., 2009; Negm et al., 2014). The lower performance of Cydnoseius negevi towards Achroia grisella eggs may be due to 1) inadequacies of level of certain nutrients of eggs required for developing their ovarioles or eggs, 2) it could be caused also by the presence of an antifeeding factor in the eggs. The oviposition rate of Amblyseius swirskii on Achroia grisella eggs was higher than those fed on bee pollen ( $0.14 \mathrm{eggs} / Q)$, date pollen $(8.7 \mathrm{eggs} / Q)$ and the acarid mite Tyrophagus putrescentiae (Schrank) (3.69 eggs/o) and comparable with those fed on Rhyncaphytoptus ficifoliae Keifer (20.0 eggs/o) (Diptilomiopidae) and the mango red spider mite Oligonychus mangiferus (Rahman and Sapra) (20.9 eggs/o) (Abou-Awad et al., 1999, 2010; Riahi et al., 2017a,b). When Neoseiulus barkeri fed on Eutetranychus kankitus Ehara and Panonychus citri (McGregor) as natural prey, the oviposition rate was higher than those fed on Achroia grisella eggs presently (Ying Li et al., 2017). Fecundity of Neoseiulus barkeri on Tyrophagus putrescentiae, Aleuroglyphus ovatus as unnatural foods was comparable with the rate recorded on insect eggs (Xia et al., 2012; Ying Li et al., 2017).

\section{Conclusion}

In conclusion, the results of the present study indicate the possibility of using Achroia grisella eggs as unnatural food for mass-rearing of Neoseiulus barkeri and Amblyseius swirskii, potentially reducing production costs and encouragement wider use of theses biological control agents. Therefore, Achroia grisella can be easily and inexpen- 
sively reared according to the cheap component of used diet that could be good candidate as unnatural food for rearing above predators. The possibility of using Achroia grisella eggs evaluated presently for mass rearing of Amblyseius swirskii and Neoseiulus barkeri, is acceptable as of lower cost than using spider mites as natural prey, and also of the smaller space of rearing predators and reduced labor needed.

\section{Literature}

Abou-Awad, B. A., Nasr A. K., Gomaa, E. A. and Abou- Elela, M. M. (1989): Life history of the predatory mite, Cydnodromella negevi and the effect of nutrition on its biology (Acari: Phytoseiidae). Ins. Sci. Applic. 10, 617-623.

Abou-Awad, B. A., El-Sawaf, B. M. and Abdel-Khalek, A. A. (1999): Impact of two eriophoid fig mites, Aceria ficus and Rhyncaphytoptus ficifoliae, as prey on postembryonic development and oviposition rate of the predacious mite A. swirskii. Acarologia 40, 367-371.

Abou-Awad, B. A., Metwally, A. and Al-Azzazy, M. (2010): Typhlodromips swirskii (Acari: Phytoseiidae) a predator of eriophyid and tetranychid mango mites in Egypt. Acta Phytopathol. et Entomol. Hung. 45, 135-148.

Abou-Elella, G. M. (2003): Thrips tabaci (Lind.) as suitable prey for three predacious mites of the family Phytoseiidae (Acari: Phytoseiida). J. Agric. Sci. Man. Univ. 28, 6933-6939.

Arthurs, S., Mckenzie, C. L., Chen, J., Dogramaci, M., Brennan, M., Houben, K. and Osborne, L. (2009): Evaluation of Neoseiulus cucumeris and Amblyseius swirskii (Acari: Phytoseiidae) as biological control agents of chilli thrips, Scirtothrips dorsalis (Thysanoptera: Thripidae) on pepper. Biol. Cont. 49, 91-96.

Birch, L. C. (1948): The intrinsic rate of natural increase in an insect population. J. Anim. Ecol. 17, 15-26.

Buitenhuis, R., Murphy, G., Shipp, L. and Scott-Dupree, C. (2015): Amblyseius swirskii in greenhouse production systems: a floricultural perspective. Exp. Appl. Acarol. 65, doi:10.1007/s10493-014-9869-9.

Chang, C. P. and Hsieh, F. K. (1992): Morphology and bionomics of Galleria mellonella. Chin. J. Entomol. 12 , 121-129.

Chi, H. (1988): Life-table analysis incorporating both sexes and variable development rates among individuals. Env. Ent. 17, 26-34.

Chi, H. (2017): TWO SEX-MSChart: A computer program for the age-stage, Two-sex life table analysis http://140.120.197.173/Ecology/Download/TwosexMSChart.zip.

Chi, H. and Liu, H. (1985): Two new methods for the study of insect population ecology. Bull. Inst. Zool. Acad. Sin. 24, 225-240.

Ebadi, R. (1975): Wax of bee. J. Iran. Entomol. 10, 61-64.

El-Sawi, S. A. and Momen, F. M. (2005): Biology of some phytoseiid predators (Acari: Phytoseiidae) on eggs of Phthorimaea operculella and Spodoptera littoralis (Lepidoptera: Gelechidae and Noctuidae). Acarologia 46, 23-30.

Gerson, U., Smiley, R. L. and Ochoa, R. (2003): Mites (Acari) for Pest Control. Blackwell Science, UK, 534 p.

Hansen, L. S. (1988): Control of Thrips tabaci (Thysanoptera : Thripidae) on glasshouse cucumber using large introductions of predatory mites Amblyseius barkeri (Acarina : Phytoseiidae). Entomophaga 33, 33-42.

Huang, Y. B. and Chi, H. (2013): Life tables of Bactrocera cucurbitae (Diptera: Tephritidae): with an validation of the jackknife technique. J. Appl. Ent. 137, 327-339.

Huang, H., Xu, X. N., Lv, J. L., Li, G. T., Wang, E. D. and Gao, Y. L. (2013): Impact of proteins and saccharides on mass production of Tyrophagus putrescentiae (Acari: Acaridae) and its predator Neoseiulus barkeri (Acari: Phytoseiidae). Bio. Sci. Tec. 23, 1231-1244.

Ji, J., Zang, Y., Lin, J., Chen, X., Sun, L. and Saito, Y. (2015): Life histories of three predatory mites feeding upon Carpoglyphus lactis (Acari, Phytoseiidae; Carpoglyphidae). Sys. App. Acarol. 20, 491-496.

McMenamin, A. J. and Genersch, E. (2015): Honey bee colony losses and associated viruses. Cur. Opi. Ins. Sci. 8, 121-129.

McMurtry, J. A., De Moraes, G. J. and Sourassou, N. F. (2013): Revision of the lifestyles of phytoseiid mites (Acari: Phytoseiidae) and implications for biological control strategies. Sys. Appl. Acarol. 18, 297-320. 
Midthassel, A., Leather, S. and Baxter, I. (2013): Life table parameters and capture success ratio studies of Typhlodromips swirskii (Acari: Phytoseiidae) to the factitious prey Suidasia medanensis (Acari: Suidasidae). Exp. Appl. Acarol. 61, 69-78.

Momen, F. M. (1995): Feeding, development and reproduction of Amblyseius barkeri (Acarina: Phytoseiidae) on various kinds of food substance. Acarologia 36, 101-105.

Momen, F. M. (2009): Potential of three species of predatory phytoseiid mites as biological control agents of the peach silver mite, Aculus fockeui (Acari: Phytoseiidae and Eriophyidae). Acta Phytopathol. et Entomol. Hung. 44, 151-158.

Momen, F. M. and El-Borolossy, M. E. (1999): Suitability of the citrus brown mite, Eutetranychus orientalis as prey for nine species of phytoseiid mites (Acari: Tetranychidae : Phytoseiidae). Acarologia 40, 19-30.

Momen, F. M. and El-Laithy, A. Y. (2007): Suitability of the flour moth Ephestia kuehniella (Lepidopter: Pyralidae) for three predatory phytoseiid mites (Acari: Phytoseiidae) in Egypt. Int. J. Trop. Ins. Sci. 27, 102-107.

Momen, F. M. and Abdel-Khalek, A. (2008): Effect of the tomato rust mite Aculops lycopersici (Acari: Eriophyidae) on the development and reproduction of three predatory phytoseiid mites. Int. J. Trop. Ins. Sci. 28, 53-57.

Momen, F. M., Abdel-Khalek, A. and El-Sawi, S. (2009): Life tables of the predatory mite Typhlodromus negevi feeding on prey insect species and pollen diet (Acari: Phytoseiidae). Acta Phytopathol. et Entomol. Hung. 44, 353-363.

Momen, F. M., Nasr, A. K., Metwally, A. M., Mahmoud, Y. A. and Saleh, K. M. (2016): Performance of five species of phytoseiid mites (Acari: Phytoseiidae) on Bactrocera zonata eggs (Diptera: Tephritidae) as a factitious food. Acta Phytopathol. et Entomol. Hung. 51, 127-136.

Negm, M. W., Alatawi, J. and Aldryhim, Y. N. (2014): Biology, predation, and life table of Cydnoseius negevi and Neoseiulus barkeri (Acari: Phytoseiidae) on the old world date mite, Oligonychus afrasiaticus (Acari: Tetranychidae). J. Ins. Sci. 14, 1-6.

Nguyen, D. T., Vangansbeke, D. and De Clercq, P. (2014): Artificial and factitious foods support the development and reproduction of the predatory mite Amblyseius swirskii. Exp. App. Acarol. 62, 181-194.

Riahi, E., Fathipour, Y., Talebi, A. A. and Mehrabadi, M. (2017a): Natural diets versus factitious prey: comparative effects on development, fecundity and life table of Amblyseius swirskii (Acari: Phytoseiidae). Sys. Appl. Acarol. 22, 711-723.

Riahi, E., Fathipour, Y., Talebi, A. A. and Mehrabadi, M. (2017b): Linking life table and consumption rate of Amblyseius swirskii (Acari: Phytoseiidae) in presence and absence of different pollens. Ann. Entomol. Soc. Amer. 110, 244-253.

Sawaf, M. S. (1962): Effect of some artificial diets on lifespan of the greater wax moth Galleria mellonella L. Bull. Entomol. Soc. Egypt. 13, 212-217.

van Lenteren, J. C. (2012): The state of commercial augmentative biological control: plenty of natural enemies, but a frustrating lack of uptake. BioControl 57, 1-20.

Wade, M. R., Zalucki, M. P., Wratten, S. D. and Robinson, K. A. (2008): Conservation biological control of arthropods using artificial food sprays: current status and future challenges. Bio. Cont. 45, 185-199.

Xia, B., Zou, Z., Li, P. and Lin, P. (2012): Effect of temperature on development and reproduction of Neoseiulus barkeri (Acari: Phytoseiidae) fed on Aleuroglyphus ovatus. Exp. Appl. Acarol. 56, 33-41.

Ying Li, Y., Hao Zhang, G., Bei Tian, C., Xiu Liu, M., Qing Liu, Y., Liu, H. and Jun Wang, J. (2017): Does long-term feeding on alternative prey affect the biological performance of Neoseiulus barkeri (Acari: Phytoseiidae) on the target spider mites? J. Econ. Entomol. 110, 915-923.

Zhang, Z. Q. (2003): Mites of Greenhouses: Identification, Biology and Control. CABI Publishing, Wallingford, UK, 244 p. 